\title{
Modeling the Size of the Mutual Fund Industry in Countries of Central and Eastern Europe
}

\section{Oleksandra Lemeshko, Oldřich Rejnuš}

\author{
Masaryk University \\ Faculty of Economics and Administration, Department of Finance \\ Lipová 5a, 60100 Brno, Czech Republic \\ E-mail: lemeshko@mail.muni.cz, rejnus@econ.muni.cz
}

\begin{abstract}
The rapid growth and development of the mutual fund industry throughout the world stimulated vast contemporary studies focusing on a wide range of issues predominantly of microeconomic character, such as fund performance, timing ability, fees and fund flows, thus leaving determinants and attributes of mutual fund industry development beyond their research. The rare relevant studies predict that development of the mutual fund industry depends on a number of factors among which the predominant role belongs to development of the economic and financial systems, and quality of governance and regulatory basis. One essential condition of validity of this prediction is that it is based upon a sample of developed economies, thus leaving a space for the likelihood that under condition of developing or middle-income economies some expectations may substantially deviate from the predication. This paper aims to reevaluate the significance of the impact of individual macro- and microeconomic factors, which were identified in previous studies, on size of asset under management in the sample of high-and middle-income economies of Central and Eastern Europe by means of regressing the total size of the mutual fund industry and size of its separate components, such as equity, fixed income and money market asset management over a number of independent variables. The obtained results indicate that out of a wide range of factors, the high explanatory power of which was stressed by earlier studies, only a small group of them turned out to be significant in our research. In particular, it was found that the size of the CEE mutual fund industry in general and the sizes of its particular segments respond positively on increase of country openness to trade and capital inflows, development and stability of local financial and capital markets, improvement of quality of governance and regulatory basis. Also some controversial evidence was obtained on the role of change in government indebtedness for explaining the size of the mutual fund industry - in general, there is a significantly positive impact of a decrease of central government debt on the size of CEE asset management, however its sign is not consistent across all subcategories of funds. Although the chosen sample does not cover as large a number of countries as previous studies, it provides brief insight into the CEE mutual fund industry, documenting important country and regional characteristics.
\end{abstract}

Keywords: determinants, economic and financial system development, governance

JEL codes: G23, 016 


\section{Introduction}

Currently asset management is one of the most fast growing segments of international capital markets. Its rapid growth and development throughout the world stimulated a vast contemporary studies on wide range of issues of mainly microeconomic character, such as fund performance and timing ability, fees and expenses, fund flows, exchange traded funds (ETF) and socially responsible funds (SRF). However despite the increasing significance of asset management there is, evidently, a lack of studies on its development and growth attributes. The existing literature predicts that the mutual fund industry is more advanced in countries with better developed and more stable capital markets and a stronger regulatory basis (Beck et al., 2010; Čihák et al., 2012). The obtained results confirm that a number of factors influence the growth and development of the mutual fund industry such as national income and capital market liquidity (Fernando et al., 2003), market returns and country openness (Klapper et al., 2004). All these studies on both microeconomic characteristics and macroeconomic determinants are structured upon developed economies, thus leaving the space for substantial likelihood that under condition of developing economies some expectations may substantially deviate from these predications. In this sense the mutual fund industry in Central and Eastern Europe (CEE) provides good opportunity for further research. Existing studies structured upon CEE economies are rather scarce and restrict their interest to banks and pension funds (Havrylchyk, 2009; Jackowicz and Kowalewski, 2012) rather than mutual funds per se. As for development determinants and growth attributes of CEE asset management, there is an evident gap in relevant studies.

The existing literature predicts that the development of the mutual fund industry depends on a number of factors among which the predominant role belongs to development of economic and financial system and with quality governance. This paper aims to reevaluate on a sample of high- and middleincome CEE economies the impact of factors identified in previous studies. This study departs from previous ones by using a new database of more than 5000 open-end equity, fixed income and money market mutual funds operating in CEE during the last 13 years. Although the chosen sample does not cover as large of a number of countries as previous studies, it provides an insight into the CEE fund industry, documenting important country and regional characteristics. Following established practice, for evaluation of the significance of particular growth factors and development attributes the size of the mutual fund industry, given by its market capitalization to GDP ratio is regressed by means of pooled OLS over a number of independent variables, data on which was collected for a sample of 11 countries for a 13 year time span.

This paper proceeds as follows: Section 2 reviews the existing studies dealing with mutual fund industry in general and determinants of its development in 
particular; Section 3 reports data used and methodology applied; Section 4 discusses the significance of impact of chosen determinants of mutual fund development in CEE economies; and Section 5 concludes.

\section{Overview of Literature on Mutual Fund Industry Development}

Vast contemporary studies on mutual funds focus on wide range of issues of mainly microeconomic character, such as fund performance and timing ability, fees and expenses, fund flows, exchange traded funds (ETF) and socially responsible funds (SRF). All these studies are structured upon world samples. To evaluate mutual fund performance practitioners and academics frequently rely on various fund characteristics such as expenses and fees, past performance, fund size and age, inflows, diversification and turnover. In general, recent studies confirm this relationship. Among assumed characteristics the highest relevance have past performance and fund size (Agnesens, 2013). Additionally characteristics relating to quality of fund management, structure of management team and corporate culture are also relevant (Prather et al., 2004; Gottesman and Morey, 2006, 2012; Karagiannidis, 2010, 2012). Knowledge spillovers experienced by funds headquartered in large cities might be another relevant factor (Bell and Deng, 2013; Christoffersen and Sarkissian, 2009). Along with determinants of fund performance modern studies deal with problematic market timing. There is evidence that some of the best performing fund managers do possess shortterm market timing abilities (Bollen and Busse, 2004; Benos and Jochec, 2011). One actively investigated issue today is fund characteristics explaining total expense ratio (Korkeamaki and Smythe, 2004; Geranio and Zanotti, 2005; Adams et al., 2012). Studies estimating the extent to which mutual fund portfolio trading of securities is triggered by investor flows, indicate that the significance of this liquidity-induced portfolio trading activity is small and behavior of fund investors is more consistent with contrarian rather than momentum characteristics (Rakowski and Wang, 2009; Dubofsky, 2010). ETFs and SRF are a recent and very successful financial innovation thus being frequent subject of modern studies. Comparison of risk-adjusted performance of ETFs and closed-end funds (CEF) confirms superior performance of ETFs (Harper et al., 2006; Hughen and Mathew, 2009). Studies on SRF are focused mainly on fund's performance. Currently SRF are undergoing a catching up phase and thus there is no evidence of significant differences in risk-adjusted returns between SRF and conventional funds (Bauer et al., 2005; Benson and Humphrey, 2008).

However despite such growth and development of the mutual fund industry, there is an evident lack of studies on their determinants and attributes. The existing literature predicts that the mutual fund industry is more advanced in countries with better developed and more stable capital markets and a stronger 
regulatory basis (Beck et al., 2010). The obtained results confirm that highincome economies experience higher growth rates of domestic mutual fund industries relative to their middle-income neighbors, reflecting investor confidence in market integrity and liquidity, and efficiency of local regulatory systems (Fernando et al., 2003). However, the existing evidence on middleincome economies comes mainly from the experience of Asian countries which were hit by the East Asian crisis, thus imposing some uncertainty about unbiasedness of the obtained results. As for other attributes of development of the mutual fund industry there is empirical evidence of significant positive correlation between local mutual fund growth rates and such variables as market returns, country openness and common law (Klapper et al., 2004). Further studies suggest that the industry is larger in countries with wealthier and more educated populations, where the industry is older and in which defined contribution pension plans are more prevalent (Khorana et al., 2005). Studies exploring the role of institutional and socio-cultural factors as further determinants of differential development and growth rates of the mutual fund industry indicate at insignificantly negative impact of unified financial service industry regulatory framework, which is used by all member states of the European Union, as well as a negative impact of widespread belief in work as the legitimate source of monetary gain (Tulbure and Catarama, 2009). Alongside evidence in favor of dependence on particular macroeconomic factors there is also some evidence for some determination by microeconomic characters such as competition and contestability within industry: fewer barriers to entry and lower initial and redemption charges are positively associated with a larger mutual fund industry (Ramos, 2009). Here it is necessary to state that all above mentioned studies are structured upon world samples, which are mainly represented by well developed economies. Thus interesting results would be obtained by investigating the development of mutual fund industry in developing economies, such as Brazil. It seems surprising, but common variables like economic development, market returns and quality of regulation were not found to be statistically significant, while financial innovations and market risk did affect the relative development of the domestic mutual fund industry (Varga and Wengert, 2010).

As for performance of individual sectors of the mutual fund industry, the existing evidence indicates that, on average: (1) equity and fixed income funds underperform relative to benchmark, which is the result of fund managers' weak selection skills and successful timing strategies; (2) more concentrated equity funds perform better, that is, investment ability is more evident among equity fund managers who hold portfolios concentrated in a few industries; (3) high yield fixed income funds exhibit persistence in their monthly returns; (4) money market funds returns are considered as immune to runs and financial instability (Pastor and Stambaugh, 2001; Breloer et al, 2012; Ammann et al, 2010; Huij and Derwall, 2007; Jank and Wedow, 2008). Existing studies on 
development of individual sectors of the mutual fund industry indicate that, on average: (1) all three categories of funds grow faster in countries with better macroeconomic performance and higher investors' confidence in the integrity of local capital markets; (2) equity funds are more developed in countries where investors have higher risk tolerance and where there are lower transaction costs; (3) fixed income funds are the dominating category of funds in countries in which reforms of social security and pension systems are taking place; (4) money market funds grow faster in countries, where there is a constant monitoring of explicit and implicit guarantees issued by the banking sector; (5) once investors switch into equity funds, they are unlikely to return to fixed income or money market funds as long as equity returns are higher in real terms and their volatility is not intolerably high (Klapper, 2004; Thapa and Poshakwale, 2010, 2012; Poshakwale and Thapa, 2011; Narulita and Parwada, 2012).

All these studies on both microeconomic characteristics and macroeconomic determinants are structured upon developed economies. Thus the probability that under conditions of developing economies some expectations derived from the evidence of developed economies may either not to fulfill or even have an opposite effect - such probability cannot be excluded. In this sense the growing economic significance and fragmentation of the European mutual fund industry provides a good opportunity for relevant research. All studies on both development and particular characteristics of the European mutual fund industry can be conventionally divided into two groups - studies structured upon evidence from matured EU economies and studies structured upon developed and developing economies of Central and Eastern Europe (CEE). As other distinct features it is possible to point that: (1) all these studies have been conducted either at the individual country level, e.g., for funds that invest in Germany, UK or Italy (Walter and Weber, 2006; Cuthbertson and Nitzsche, 2013; Cuthbertson et al, 2008; Geranio and Zanotti, 2005), or on the group country level, e.g. EU-15 (Bengtsson and Delbecque, 2011); (2) all these studies focus mainly on individual characteristics of European mutual funds, in particular on their performance (Banegas et al., 2013; Vidal-García, 2013), and leave out their macroeconomic determinants and attributes. Thus based on review of recent and sometimes all existing studies it is possible to conclude that there is a large gap in research of functional characteristics and growth determinants of mutual fund industry in countries of Central and Eastern Europe (CEE). Former communist and currently developed and developing market economies of CEE, having among themselves EU and non-EU members, provide an excellent opportunity to test whether the relationship between maturation of national economical and financial systems and mutual fund industry development, also holds in less efficient markets. Relevant studies structured upon CEE economies are rather scarce and restrict their interest to banks (Havrylchyk, 2009; Jackowicz et al., 2011) and pension funds (Bakker and 
Gross, 2004; Aspalter, et al, 2009) rather than mutual funds per se. Rest scientific issues from CEE economies remain practically unknown. Rare existing modern studies indicate that equity market development and competition in the banking sector play a significant positive role in sparing overall economic growth and asset management industry of CEE economies independently from their economic association (Bakker and Gross, 2004; Cojocaru et al., 2011). Recent country studies on funds confirm overall short-term performance persistence of Hungarian equity mutual funds (Erdos and Ormos, 2009; Dariusz, 2011). There is evidence of slight outperformance of Polish funds relative to international funds due to informational advantages of local over foreign investors, and presence of market timing ability (Białkowski and Otten, 2011). As for determinants and attributes of CEE mutual fund industry growth, so far to our knowledge there is no a single study on this subject.

\section{Data and Methodology}

This paper aims to reevaluate on a sample of developed and developing CEE economies the impact of factors identified in previous studies and presented above. For research design purposes and on the basis of World Bank income approach, 11 CEE economies have been divided into two groups - high-income CEE economies with $\$ 801.08$ billion of total GDP or $\$ 13,517$ per capita, comprising Poland, Czech Republic, Slovakia, Hungary, Slovenia and Estonia, and middle-income CEE economies with $\$ 1,169.56$ billion of total GDP or $\$ 6,199$ per capita, comprising Latvia, Lithuania, Russia, Ukraine and Belarus. This study departs from previous ones by using a new database of more than 5,000 open-end equity, fixed income and money market mutual funds operating in CEE in the time-window of 2000-2014. Although the chosen sample does not cover as large of a number of countries as previous studies, it provides an insight into the CEE fund industry, documenting important country and regional characteristics. Following established practice, the average marginal effect of longitudinal data (cross-sectional, that is, for 11 entities in the sample, and times-series, that is, for 13 observation periods) was analyzed by means of fixed effect estimator with $95 \%$ statistical significance. The longitudinal data used was of both raw and ready-made character and it was collected from various sources: (1) data for variables referring to capital market and mutual fund industry development was partly derived from Bloomberg and partly provided by Investment Company Institute (ICI), European Securities and Markets Authority (ESMA), and European Fund and Asset Management Association (EFAMA); (2) data for variables of economic and social development was derived from the World Bank (WB) and International Monetary Fund (IMF) databases - World Development Indicators (WDI) and International Financial Statistics (IFS), as well as from the United Nations Organization (UNO) database; (3) data for variables of quality of regulatory basis and governance was derived from database by Kaufmann et al. (2009) - The Worldwide Governance Indicators, 2013 Update (See Table 1 and Table 2). The applied 
approach was comprised by the following sequence of steps: (1) identification of the full range of potential determinants and choice of representative variables (proxies) on the basis of empirical evidence and existing studies; (2) setting up, adjusting the database (especially in the case of Bloomberg, raw data which required manual corrections for outliers), dropping out of observations with missing values; (3) specification of the model (choice of its functional form and type, that is, pooled OLS versus fixed effect or random effect estimator); (4) check of the obtained estimates for robustness.

A mutual fund, also widely known as assets under management (AUM), stands for a market value of assets that an investment company manages on behalf of its investors. Aggregate assets under management of a group of investment companies operating within an economy at a given overall market price level in a given time period is defined as mutual fund industry. There are many ways how to measure mutual fund industry - in terms of number of funds either domiciled or available (or both) for local and foreign investors, funds' total assets or funds' net assets. Although all these indicators provide good measurement of mutual fund industry which is consistent over time and between countries, nevertheless it has poor evaluating power due to absolute nature of the indicators used. Absolute indicators do not allow evaluation of the role and significance of any economic unit or system in terms of a whole country's economy or social welfare. In contrast, relative indicators view any economic unit or system as a component of a larger group of economic units or a super system, for example, a country's economy or social welfare allow evaluation of the role and significance of the former (i.e. an economic unit or system) in the development and growth of the latter (i.e. a group of economic units or a super system) (Vinkler, 2012). One relative measure of size of a country's mutual fund industry accepted worldwide is market value of total assets under management of operation in the country mutual funds as fraction of the country's GDP. This measurement is used by both academicians (Fernando et al., 2003; Klapper et al., 2004; Khorana et al., 2005; Tulbure and Catarama, 2009) and practitioners (The Global Financial Development Database 2013 by Čihák et al. (2012) from the WB; Asset Management Annual Report: Facts and Figures $7^{\text {th }}$ Annual Review by group of experts from EFAMA). In our research we will follow this approach.

The existing literature predicts that development of mutual fund industry depends on a number of factors among which the predominant role belongs to the development of economic and financial systems and quality of governance. In particular, existing studies confirm that, on average, financial intermediaries are larger, more active and more efficient in high-income countries with lower income heterogeneity (Demirguc-Kunt, 2011). Further it is natural to assume that financial intermediaries will be larger in countries, where consumers are better educated and have better access to information (both printed and online sources), financial institutions and markets (Khorana et al., 2005). Besides 
overall economic development, openness to trade and capital flows, being an indicator of integration with international capital and goods markets, is particularly important for promotion of countries' financial systems and asset management (Čihák et al., 2012). In this context it is important not to forget that openness is closely interconnected with risk to cross-border financial contingency and crisis (Laeven and Valencia, 2012). In light of the above stated it is expected that while analyzing determinants of asset management development it is necessary to operate with such explanatory variables as GDP per capita and Gini index, literacy rate, average number of newspapers and internet users per capita, total trade to GDP ratio, sovereign debt to GDP ratio, FDI to GDP ratio, and financial crisis dummy variable (See Table 1).

Emergence and development of asset management can be viewed as a further stage of financial system maturation. Thus while investigating fund industry development a number of explanatory variables referring to financial system development should be taken into consideration: size of capital market, its turnover and liquidity, size of banking sector and its ability to transfer funds, bank concentration ratio, size of insurance sector, real interest rates, return of local exchange index and its volatility (Fernando et al., 2003; Klapper et al., 2004; Beck et al., 2010; Demirguç-Kunt, 2011; Čihák et al., 2012) (See Table $1)$. 
Table 1 Chosen attributes of CEE mutual fund industry growth and development

Variable

\section{Panel A. Economic growth and development characteristics}

\begin{tabular}{|c|c|c|c|}
\hline Log GDP per capita* & Log of annual country GDP per one inhabitant. & Klapper et al. (2004) & WDI, IMF \\
\hline GDP growth rate* & Annual growth rate of country GDP. & Klapper et al. (2004) & WDI, IMF \\
\hline Gini index* & $\begin{array}{l}\text { A measure of country } \\
\text { residents' annual income distribution. It is the } \\
\text { most popular measure of inequality, widely used } \\
\text { by UNO, WB, IMF. }\end{array}$ & $\begin{array}{l}\text { Fernando et al. (2003), } \\
\text { Klapper et al. (2004), } \\
\text { Khorana et al. (2005) }\end{array}$ & UNO \\
\hline Literacy rate* & $\begin{array}{l}\text { The percentage of the population age } 15 \text { and } \\
\text { above who can, with understanding, read and } \\
\text { write a short, simple statement on their } \\
\text { everyday life. It is one of the most popular } \\
\text { measures of human capital development, widely } \\
\text { used by UNO, WB, IMF. }\end{array}$ & Khorana et al. (2005) & WDI, UNO \\
\hline Newspapers per capita* & $\begin{array}{l}\text { The average number of newspapers available in } \\
\text { the country per one inhabitant. }\end{array}$ & Khorana et al. (2005) & WDI, UNO \\
\hline Internet users per capita* & $\begin{array}{l}\text { The average number of internet users in the } \\
\text { country per one inhabitant. }\end{array}$ & Khorana et al. (2005) & WDI, UNO \\
\hline Total trade to GDP ratio* & $\begin{array}{l}\text { Country exports and imports to GDP. It stands } \\
\text { for country openness to trade. }\end{array}$ & Laeven and Valencia (2012) & $\begin{array}{l}\text { Laeven and Valencia } \\
\text { (2012), } \\
\text { IMF, WDI }\end{array}$ \\
\hline FDI to GDP ratio* & $\begin{array}{l}\text { Country foreign direct investments to GDP. It } \\
\text { stands for country openness to capital flows }\end{array}$ & Čihák et al. (2012) & WDI, IMF \\
\hline Financial crisis* & $\begin{array}{l}\text { Dummy variable, } 1 \text { - for no crisis and } 0 \text { - for } \\
\text { crisis. }\end{array}$ & $\begin{array}{l}\text { Laeven and Valencia (2012), } \\
\text { Čihák et al. ( 2012) }\end{array}$ & $\begin{array}{l}\text { Laeven and Valencia } \\
\text { (2012), } \\
\text { IMF }\end{array}$ \\
\hline
\end{tabular}

Panel B. Financial market development characteristics

Cap to GDP ratio* Market capitalization of listed stocks to GDP in $\quad$ Fernando et al. (2003),




\begin{tabular}{|c|c|c|c|}
\hline & the country. & Klapper et al. (2004) & (2011), WDI, IMF \\
\hline $\begin{array}{l}\text { Total shares traded to } \\
\text { GDP ratio** }\end{array}$ & $\begin{array}{l}\text { Turnover of listed stocks to GDP in the country. } \\
\text { It stands for capital market liquidity. }\end{array}$ & $\begin{array}{l}\text { Fernando et al. (2003), } \\
\text { Klapper et al. (2004) }\end{array}$ & $\begin{array}{l}\text { Demirguc-Kunt } \\
(2011), \text { WDI, IMF }\end{array}$ \\
\hline $\begin{array}{l}\text { Total shares traded to } \\
\text { Cap ratio** }\end{array}$ & $\begin{array}{l}\text { Turnover of listed stocks to market } \\
\text { capitalization. It stands for capital market } \\
\text { turnover. }\end{array}$ & $\begin{array}{l}\text { Fernando et al. (2003), } \\
\text { Klapper et al. (2004) }\end{array}$ & $\begin{array}{l}\text { Demirguc-Kunt } \\
\text { (2011), WDI, IMF }\end{array}$ \\
\hline $\begin{array}{l}\text { Total bank assets to GDP } \\
\text { ratio* }\end{array}$ & $\begin{array}{l}\text { Total commercial bank assets to GDP in the } \\
\text { country. It stands for a size of banking industry. }\end{array}$ & $\begin{array}{l}\text { Fernando et al. (2003), } \\
\text { Klapper et al. (2004) }\end{array}$ & $\begin{array}{l}\text { Demirguc-Kunt } \\
(2011), \text { WDI, IMF }\end{array}$ \\
\hline $\begin{array}{l}\text { Share of total bank assets } \\
\text { held by top three banks* }\end{array}$ & $\begin{array}{l}\text { Share of total bank assets held by top three } \\
\text { banks to total commercial bank assets in the } \\
\text { country. It stands for bank concentration. }\end{array}$ & $\begin{array}{l}\text { Fernando et al. (2003), } \\
\text { Klapper et al. (2004) }\end{array}$ & $\begin{array}{l}\text { Demirguc-Kunt } \\
\text { (2011), WDI, IMF }\end{array}$ \\
\hline $\begin{array}{l}\text { Total bank credits to total } \\
\text { bank deposits ratio* }\end{array}$ & $\begin{array}{l}\text { Private credit by deposit money banks as a } \\
\text { share of demand, time and saving deposits in } \\
\text { deposit money banks in the country. }\end{array}$ & Khorana et al. (2005) & $\begin{array}{l}\text { Demirguc-Kunt } \\
\text { (2011), WDI, IMF }\end{array}$ \\
\hline $\begin{array}{l}\text { Total life and non-life } \\
\text { insurance assets to GDP } \\
\text { ratio* }\end{array}$ & $\begin{array}{l}\text { Total life and non-life insurance assets to GDP in } \\
\text { the country. It stands for a size of insurance } \\
\text { industry. }\end{array}$ & Khorana et al. (2005) & $\begin{array}{l}\text { Demirguc-Kunt } \\
\text { (2011), }\end{array}$ \\
\hline Real interest rates* & $\begin{array}{l}\text { Average annual deposit rates adjusted for } \\
\text { annual inflation rate. }\end{array}$ & $\begin{array}{l}\text { Fernando et al. (2003), } \\
\text { Klapper et al. (2004), } \\
\text { Khorana et al. (2005) }\end{array}$ & Bloomberg \\
\hline Return of local MSCI** & $\begin{array}{l}\text { Annual average of the MSCI monthly return } \\
\text { index of real local } \\
\text { market return. It is the most commonly used } \\
\text { indicator of market performance. It stands for a } \\
\text { return of local stock market. }\end{array}$ & $\begin{array}{l}\text { Fernando et al. (2003), } \\
\text { Klapper et al. (2004), } \\
\text { Khorana et al. (2005) }\end{array}$ & Bloomberg \\
\hline Volatility of local MSCI** & $\begin{array}{l}\text { Annual standard deviation of the MSCI monthly } \\
\text { return index of } \\
\text { real local market return. It is the most } \\
\text { commonly used indicator of market volatility. It } \\
\text { stands for volatility of local stock market. }\end{array}$ & $\begin{array}{l}\text { Fernando et al. (2003), } \\
\text { Klapper et al. (2004), } \\
\text { Khorana et al. (2005) }\end{array}$ & Bloomberg \\
\hline \multicolumn{4}{|c|}{ Panel C. Quality of governance characteristics } \\
\hline Voice and accountability* & $\begin{array}{l}\text { Reflects country citizens' perceptions of the } \\
\text { extent of their capability } \\
\text { to effect their government selection. }\end{array}$ & $\begin{array}{l}\text { La Porta et al. (1998), } \\
\text { Klapper et al. (2004), } \\
\text { Khorana et al. (2005), }\end{array}$ & $\begin{array}{l}\text { Kaufmann et al. } \\
\text { (2009), WB }\end{array}$ \\
\hline
\end{tabular}




\begin{tabular}{|c|c|c|c|}
\hline & $\begin{array}{l}\text { It also stands for citizens' assessment of } \\
\text { freedom of expression, freedom of association, } \\
\text { and a free media. }\end{array}$ & Kaufmann et al. (2009) & \\
\hline Political stability* & $\begin{array}{l}\text { Reflects country citizens' perceptions of the } \\
\text { probability of unconstitutional overthrow and } \\
\text { government default, including terrorism. }\end{array}$ & $\begin{array}{l}\text { La Porta et al. (1998), } \\
\text { Klapper et al. (2004), } \\
\text { Khorana et al. (2005), } \\
\text { Kaufmann et al. (2009) }\end{array}$ & $\begin{array}{c}\text { Kaufmann et al. } \\
\text { (2009), WB }\end{array}$ \\
\hline $\begin{array}{l}\text { Government } \\
\text { effectiveness* }\end{array}$ & $\begin{array}{l}\text { Reflects country citizens' perceptions of the } \\
\text { quality of public services provided and public } \\
\text { polices implemented. }\end{array}$ & $\begin{array}{l}\text { La Porta et al. (1998), } \\
\text { Klapper et al. (2004), } \\
\text { Khorana et al. (2005), } \\
\text { Kaufmann et al. (2009) }\end{array}$ & $\begin{array}{c}\text { Kaufmann et al. } \\
\text { (2009), WB }\end{array}$ \\
\hline Regulatory quality* & $\begin{array}{l}\text { Reflects country citizens' perceptions of the } \\
\text { quality of government policies aimed at } \\
\text { promotion of private initiative. }\end{array}$ & $\begin{array}{l}\text { La Porta et al. (1998), } \\
\text { Klapper et al. (2004), } \\
\text { Khorana et al. (2005), } \\
\text { Kaufmann et al. (2009) }\end{array}$ & $\begin{array}{c}\text { Kaufmann et al. } \\
\text { (2009), WB }\end{array}$ \\
\hline Control of corruption* & $\begin{array}{l}\text { Reflects country citizens' perceptions of the } \\
\text { extent to which public power is exercised for } \\
\text { private gain. }\end{array}$ & $\begin{array}{l}\text { La Porta et al. (1998), } \\
\text { Klapper et al. (2004), } \\
\text { Khorana et al. (2005), } \\
\text { Kaufmann et al. (2009) }\end{array}$ & $\begin{array}{c}\text { Kaufmann et al. } \\
\text { (2009), WB }\end{array}$ \\
\hline
\end{tabular}

* Annual data

** Annualized data on the basis of monthly data, own computation 
Table 2 Descriptive statistics for chosen variables

\begin{tabular}{|c|c|c|c|c|c|c|}
\hline & \multicolumn{2}{|c|}{ All economies } & \multicolumn{2}{|c|}{$\begin{array}{c}\text { High-income } \\
\text { economies }\end{array}$} & \multicolumn{2}{|c|}{$\begin{array}{c}\text { Middle-income } \\
\text { economies }\end{array}$} \\
\hline & Median & IQR* & Median & IQR & Median & IQR \\
\hline \multicolumn{7}{|c|}{ Panel A. Mutual fund industry development characteristics } \\
\hline All mutual funds (MF), bln USD & 385.47 & 1329.70 & 536.16 & 1282.70 & 133.47 & 1265.20 \\
\hline Equity MF, bln USD & 128.25 & 498.13 & 199.66 & 467.64 & 15.46 & 521.55 \\
\hline Fixed income MF, bln USD & 62.08 & 124.05 & 102.84 & 174.28 & 15.99 & 86.08 \\
\hline Money market MF, bln USD & 8.41 & 34.28 & 11.61 & 59.78 & 2.01 & 22.07 \\
\hline \multicolumn{7}{|c|}{ Panel B. Economic growth and development characteristics } \\
\hline GDP per capita, thsd USD & 9.08 & 0.76 & 9.33 & 0.39 & 8.52 & 1.04 \\
\hline GDP growth rate, $\%$ & 5.01 & 2.03 & 2.01 & 3.10 & 7.58 & 3.15 \\
\hline Gini index & 30.84 & 8.87 & 27.25 & 7.69 & 34.00 & 8.83 \\
\hline Literacy rate, \% & 99.46 & 0.38 & 99.49 & 0.61 & 99.62 & 0.27 \\
\hline Newspapers per capita & 695.56 & 760.20 & 335.35 & 261.33 & 1109.00 & 347.43 \\
\hline Internet users per capita & 39.10 & 45.33 & 53.17 & 33.49 & 23.30 & 39.25 \\
\hline Total trade to GDP ratio, \% & 120.39 & 46.59 & 139.17 & 37.95 & 109.29 & 31.15 \\
\hline Sovereign debt to GDP ratio, \% & 31.00 & 30.30 & 37.20 & 23.98 & 19.59 & 25.86 \\
\hline FDI to GDP ratio, $\%$ & 5.33 & 4.76 & 4.25 & 5.10 & 3.50 & 4.99 \\
\hline Financial crisis, 1 or 0 & 1 & 0 & 1 & 0 & 1 & 1 \\
\hline \multicolumn{7}{|c|}{ Panel C. Financial market development characteristics } \\
\hline Cap to GDP ratio, \% & 24319.00 & 20836.00 & 20000.00 & 16224.00 & 12937.00 & 28261.00 \\
\hline Total shares traded to GDP ratio, \% & 781.22 & 986.04 & 625.99 & 1199.60 & 97.45 & 218.06 \\
\hline
\end{tabular}




\begin{tabular}{lcccccc}
\hline Total shares traded to Cap ratio, \% & 2907.70 & 4219.70 & 3108.50 & 4301.30 & 647.67 & 1971.00 \\
\hline Total bank assets to GDP ratio,\% & 42.21 & 34.59 & 52.02 & 26.99 & 29.62 & 28.16 \\
\hline $\begin{array}{l}\text { Share of total bank assets held by top } \\
\text { three banks, \% }\end{array}$ & 68.88 & 23.34 & 69.77 & 15.09 & 72.71 & 29.62 \\
\hline $\begin{array}{l}\text { Total bank credits to total bank deposits } \\
\text { ratio, \% }\end{array}$ & 122.36 & 68.41 & 90.60 & 66.17 & 117.90 & 61.00 \\
\hline $\begin{array}{l}\text { Total life and non-life insurance assets } \\
\text { to GDP ratio, \% }\end{array}$ & 236.61 & 173.50 & 313.75 & 79.30 & 151.00 & 89.70 \\
\hline Real interest rates, \% & 2.09 & 5.68 & 3.94 & 2.80 & 1.05 & 11.14 \\
\hline Return of local MSCI, points & 627.58 & 603.08 & 461.16 & 735.76 & 600.00 & 593.43 \\
\hline Volatility of local MSCI, points & 82.53 & 110.87 & 49.58 & 88.67 & 66.91 & 108.76 \\
\hline Panel D. Quality of governance characteristics & & & & & 41.35 \\
\hline Voice and accountability, points & 74.41 & 33.17 & 79.38 & 7.72 & & 48.32 \\
\hline Political stability, points & 67.93 & 24.63 & 75.47 & 15.05 & 52.40 & 36.53 \\
\hline Government effectiveness, points & 73.17 & 34.79 & 77.62 & 7.34 & 40.67 & 47.50 \\
\hline Regulatory quality, points & 77.94 & 39.39 & 80.95 & 9.94 & 39.71 & 49.88 \\
\hline Control of corruption, points & 64.39 & 40.64 & 70.37 & 12.80 & 29.19 & 43.76 \\
\hline \hline
\end{tabular}

${ }^{*} I Q R$ - interquartile range

Source: Own computations 
The ultimate group of factors that should be taken into consideration are the ones referring to quality of governance and regulatory basis. On the basis of studies by La Porta et al. (1998) and Kaufmann et al. (2009) it is natural to assume that demand for mutual funds will be higher, if the legal system is stronger. Following La Porta et al. (1998) and Kaufmann et al. (2009) for evaluation the impact of quality of governance and regulatory basis on mutual fund industry development the following explanatory variables are used: (1) voice and accountability; (2) political stability; (3) government effectiveness; (4) regulatory quality; (5) rule of law; and (6) control of corruption (See Table 1).

For analyzing the assumed relationship between the chosen dependent variable, that is, mutual fund industry size, and groups of chosen explanatory variables - variables standing for economic growth and development, financial and capital markets growth and development, and quality of governance and regulatory basis - multivariate OLS for panel data is used:

$$
Y=\beta_{1}+\beta_{2} X_{2}+\ldots+\beta_{K} X_{K}
$$

where: $Y$ - mutual fund industry development; $X_{i}$ - explanatory variables referring to particular characteristics of economic and financial markets development, and quality of governance; $\beta_{i}$ - estimates referring to direction and strength of examined relationship.

The chosen repressors are checked for relevance by means of t-statistic, Fstatistic and Information Criteria, that is, Akaike's Information Criterion (AIC) and Schwarz's Bayesian Information Criterion (BIC). Out of 33 chosen repressors only 25 turned to be relevant (See Table 1 and Table 2). Further by means of F-statistics test, Breusch-Pagan test, Haussman test the functional form of panel data regression was chosen - pooled OLS (the other two testing variants were fixed effect and random effect OLS). Finally, the represented regressions - for attributes explaining the total size of whole asset management in CEE, for local equity mutual fund industry, and for local fixed income and money markets mutual fund industries - are checked for robustness by means of Durbin-Watson and Breusch-Pagan tests.

\section{Results and Discussion}

Having on average $\$ 385.47$ billion of assets under management (AUM) in EUmember and CIS-member states and growing at an annual rate of $35 \%$, CEE fund industry along with Latin American counterpart occupies the leading position among the emerging mutual fund industries in the world having Islamic and Asian fund industries lagging behind (Table 2 and Lemeshko and Mukhacheva, 2014). A number of factors contributed to such outstanding growth, among which the prominent role was played by rapid economic and 
financial system development of CEE states: $\$ 1.97$ billion of cumulative regional GDP and $\$ 1.069 .15$ billion of regional market capitalization, growing at an average annual rate of $5 \%$ and $27 \%$ respectively, which are nearly twofold of EU's average. Although such development is rapid and overall regional progress in building local capital markets is impressive, the development of fund industries within CEE varies from state to state: on the one hand, there are four EU-member states, which are most important in terms of industry development - Poland, the Czech Republic and Hungary whose funds value account for more than $75 \%$ of that of CEE; and on the other one there are CIS-member states, led by Russia, whose funds growth account for more than $80 \%$ of that of CEE. Thus taking into account the gradually growing importance of CEE fund industry for the world asset management and high heterogeneity inside the group this paper aims is to identify the key determinants of such rapid growth and variety of development patterns.

Before presenting the obtained results it is necessary to state that majority of factors, on the explanatory power of which many earlier existing studies insisted, did not confirm in our research. Among factors, whose impact at $95 \%$ significance has not proved itself, there are national income heterogeneity, literacy and mass media coverage rates, susceptibility to financial contingency and crisis, capital market turnover and degree of bank concentration and intermediation in transfer of funds - these variables were dropped from the constructed regression due to low level of their low explanatory power.

On the basis of the obtained results, presented in Table 3, we find a strong positive relationship between mutual fund industry size, given by AUM to GDP ratio, and national income, openness to trade and national government indebtedness. This trend is common for all CEE economies - both EU-member states (especially strong cases are Poland, the Czech Republic and Hungary) and CIS-members states (Russia) - and it is consistent with earlier findings by Klapper et al. (2004), Khorana et al. (2005), Demirguc-Kunt (2011). Further we find that such relationship holds within a subsample of highincome CEE economies, but partly fails for their middle-income counterparts, whose asset management benefits from growth in national income, but suffers from increase in sovereign debts made by their national governments. This can be explained by the decreasing rate of return on fixed income assets hold by local mutual funds, which is the predominant type of assets among mutual funds in middle-income CEE economies. We also find that for the development and growth of mutual fund industry in the middle-income economies the important role play countries' openness to FDI and access to Internet, which is consistent with findings by Tulbure and Catarama (2009). 
This can be explained by low rate of people savings in such economies as Russia and Ukraine, and, thus, higher dependence on foreign investment inflows from abroad.

As for attributes given by development of financial systems in CEE economies, so we find a strong positive impact of growth in local stock markets liquidity and return, and bank assets to GDP ratio, which is common for all CEE economies. Further within both high- and middle-income subgroups we find a strong negative impact of growth in stock market volatility and real interest rate on development and growth of local mutual fund industries. All these findings are consistent with evidence provided by Beck et al. (2010) and Čihák et al. (2012) and it can be explained by the crucial roles of capital markets as the major targets and banks as major providers of investments for asset management in general and for CEE mutual fund industry in particular.

The ultimate group of factors, which could potentially explain the difference in growth and development patterns of mutual fund industry across developed and developing CEE economies, constitutes those measuring development of regulatory basis and quality of governance. So we find that development and growth of local asset management across all CEE economies is strongly positively influenced by increase in freedom of expression and association, including free media, increase in quality of public and civil services provided by local authorities, and increase in formulation, implementation and longterm commitment to sound policies aimed at promotion of individual initiative and entrepreneurship. These results are consistent with evidence provided by Klapper et al. (2004) and Khorana et al. (2005). Surprisingly, but we also find the strongly opposite effect of political stability: on average, mutual fund industries grow faster in those CEE economies, where there is higher probability of unconstitutional overthrow and government takeover. This could be the case of Russian and Ukrainian asset management under which conditions of abnormal political risk and risk of national government default offers high risk premiums, and, thus above-average local funds outperformance. 
Table 3 Determinants of mutual fund industry size in CEE economies, pooled OLS

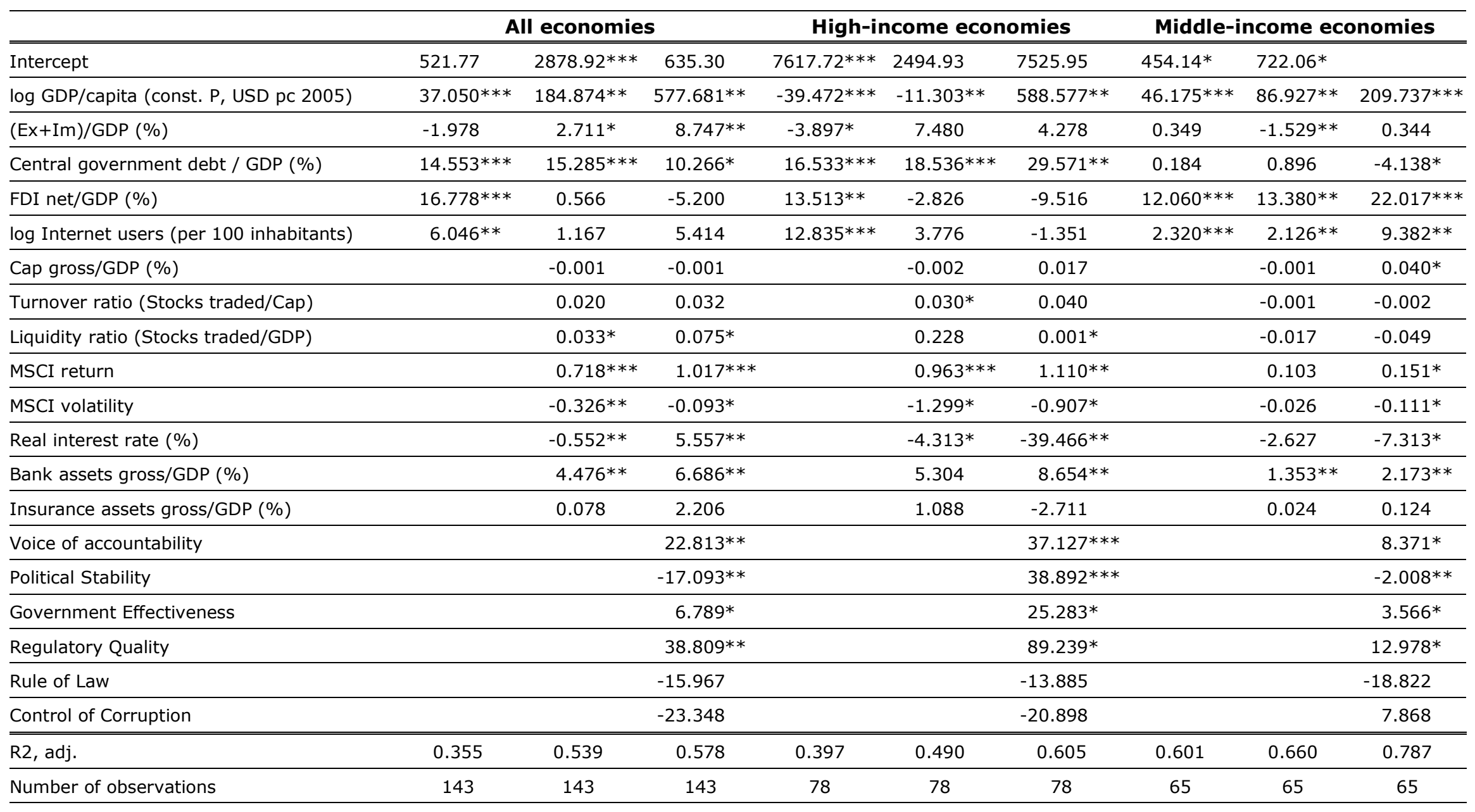

Table shows results for pooled OLS regressions with White's standard errors.

$*, * *$, and $* * *$ show significance at $10 \% .5 \%$ and $1 \%$.

Source: Own computation 
Table 4 Determinants of equity mutual fund industry size in CEE economies, pooled OLS

\begin{tabular}{|c|c|c|c|c|c|c|c|c|c|}
\hline \multirow[b]{2}{*}{ Intercept } & \multicolumn{3}{|c|}{ All economies } & \multicolumn{3}{|c|}{ High-income economies } & \multicolumn{3}{|c|}{ Middle-income economies } \\
\hline & $-408.56^{*}$ & -139.68 & $351.840 * *$ & $370.950 *$ & $-375.600 *$ & 947.360 & $-621.940 *$ & $-256.300 *$ & $-231.540 * *$ \\
\hline log GDP/capita (const. P, USD pc 2005) & $82.978 * *$ & $133.104 *$ & $-505.312 *$ & $-361.508 * * *$ & $518.784 *$ & $-171.44 * *$ & $689.927 * *$ & 446.463 & 299.174 \\
\hline$(E x+\operatorname{Im}) / G D P(\%)$ & 2.222 & $4.525^{*}$ & $4.254 * *$ & 4.225 & 5.599 & 9.198 & 4.947 & -10.526 & -4.341 \\
\hline Central government debt / GDP (\%) & $-22.128 * * *$ & $-20.681 *$ & $-16.013 * *$ & $-25.569 * * *$ & $-11.939 * *$ & $-13.049 * *$ & -1.244 & $-15.266 * * *$ & $-19.019 * * *$ \\
\hline FDI net/GDP (\%) & $20.884 *$ & 9.527 & $3.785^{*}$ & $18.080 *$ & $1.937 * * *$ & 8.333* & $81.388^{*}$ & $15.467 *$ & $59.897 *$ \\
\hline log Internet users (per 100 inhabitants) & 13.972 & 10.673 & 10.102 & 11.472 & 1.981 & 18.515 & $4.749 * *$ & $11.430 *$ & $15.088 *$ \\
\hline Cap gross/GDP (\%) & & -0.001 & 0.001 & & 0.025 & 0.040 & & -0.013 & -0.008 \\
\hline Turnover ratio (Stocks traded/Cap) & & $0.089 * *$ & $0.038^{*}$ & & $0.044 * * *$ & $0.041 * *$ & & $0.006 * *$ & $0.023 *$ \\
\hline Liquidity ratio (Stocks traded/GDP) & & $-0.350 *$ & -0.236 & & $-0.230 *$ & $-0.305^{*}$ & & $-0.285^{*}$ & -0.436 \\
\hline MSCI return & & $5.173 * * *$ & $5.535^{* * *}$ & & $6.213 * * *$ & $-0.841 * * *$ & & $7.760 *$ & $13.011 * *$ \\
\hline MSCI volatility & & $-2.197 * * *$ & $-13.405^{* *}$ & & $-67.772 * * *$ & $-48.667 *$ & & $-11.230 *$ & $14.164 *$ \\
\hline Real interest rate (\%) & & $0.506 * *$ & $0.299 *$ & & $0.157 *$ & $-0.233^{*}$ & & 1.175 & $0.643 *$ \\
\hline Bank assets gross/GDP (\%) & & $2.691 *$ & 1.818 & & $1.651 *$ & 1.185 & & 1.379 & $0.456 *$ \\
\hline Insurance assets gross/GDP (\%) & & 0.103 & -8.738 & & 0.024 & 50.663 & & 2.076 & 0.841 \\
\hline Voice of accountability & & & $-14.959 *$ & & & $-21.853 *$ & & & $-0.974 *$ \\
\hline Political Stability & & & $14.388^{* * *}$ & & & $113.439 * * *$ & & & 13.928* \\
\hline Government Effectiveness & & & $1.689 * *$ & & & $76.260 *$ & & & $66.722 * *$ \\
\hline Regulatory Quality & & & $23.896 *$ & & & -5.550 & & & $-24.992 *$ \\
\hline Rule of Law & & & 6.032 & & & 13.050 & & & -42.420 \\
\hline Control of Corruption & & & 351.840 & & & 947.360 & & & 21.452 \\
\hline R2, adj. & 0.2291 & 0.2973 & 0.3310 & 0.2196 & 0.2782 & 0.3060 & 0.2991 & 0.4696 & 0.4624 \\
\hline Number of observations & 143 & 143 & 143 & 78 & 78 & 78 & 65 & 65 & 65 \\
\hline
\end{tabular}

Table shows results for pooled OLS regressions with White's standard errors.

$*, * *$, and $* * *$ show significance at $10 \%, 5 \%$ and $1 \%$.

Source: Own computation 
Table 5 Determinants of fixed income mutual fund industry size in CEE economies, pooled OLS

\begin{tabular}{|c|c|c|c|c|c|c|c|c|c|}
\hline \multirow[b]{2}{*}{ Intercept } & \multicolumn{3}{|c|}{ All economies } & \multicolumn{3}{|c|}{ High-income economies } & \multicolumn{3}{|c|}{ Middle-income economies } \\
\hline & -934.63 & $-103.62 *$ & $-699.19 * *$ & $-405.74 *$ & -435.19 & $-996.73 * * *$ & $-18.56^{*}$ & 112.783* & 217.150 \\
\hline log GDP/capita (const. P, USD pc 2005) & $108.385^{*}$ & $107.913 * *$ & $74.307 * *$ & $443.347 * * *$ & 471.918* & $-119.28 *$ & 7.761 & -3.082 & $-21.082 *$ \\
\hline$(\mathrm{Ex}+\mathrm{Im}) / \mathrm{GDP}(\%)$ & 0.362 & $0.839 *$ & $0.923 * * *$ & 0.448 & $1.046 * *$ & $1.885^{* *}$ & $-0.487 *$ & $-0.636 * *$ & $-0.814 * * *$ \\
\hline Central government debt / GDP (\%) & $0.810 *$ & $2.357 * *$ & $2.484 *$ & $1.435^{*}$ & $-3.794 * *$ & $-4.734 * *$ & 0.060 & 0.575 & $0.285^{*}$ \\
\hline FDI net/GDP (\%) & $-1.841 * * *$ & -2.536 & $-2.609 * *$ & $-1.034 * * *$ & -2.126 & $-2.795 *$ & $-2.140 * *$ & -0.213 & $0.312 * * *$ \\
\hline log Internet users (per 100 inhabitants) & $0.445^{*}$ & -0.338 & $-0.290 *$ & -0.769 & -1.499 & 0.279 & $2.129 *$ & $1.864 *$ & 1.599 \\
\hline Cap gross/GDP $(\%)$ & & 0.000 & 0.001 & & -0.003 & -0.003 & & 0.000 & $0.000 *$ \\
\hline Turnover ratio (Stocks traded/Cap) & & $-0.025 *$ & $-0.023 *$ & & $-0.013 *$ & $-0.011 * *$ & & $0.001 *$ & $-0.002 * *$ \\
\hline Liquidity ratio (Stocks traded/GDP) & & $0.057 *$ & 0.047 & & $0.038^{*}$ & 0.001 & & -0.003 & 0.015 \\
\hline MSCI return & & $1.095^{* * *}$ & $0.798^{* *}$ & & $1.370 * * *$ & $0.553 * *$ & & $-0.803 * *$ & $-0.715^{*}$ \\
\hline MSCI volatility & & $0.616^{*}$ & $1.687 *$ & & $-5.357 * *$ & $-5.335^{*}$ & & $-0.496 *$ & $-1.073 *$ \\
\hline Real interest rate $(\%)$ & & $0.056 *$ & $0.019 *$ & & $0.130 *$ & $0.142 *$ & & $0.071 *$ & $0.041 *$ \\
\hline Bank assets gross/GDP (\%) & & $-0.296 *$ & $-0.202 * *$ & & -0.282 & -0.563 & & $0.004 *$ & $-0.059 *$ \\
\hline Insurance assets gross/GDP (\%) & & -10.62 & 0.382 & & 35.19 & -1.269 & & 11.84 & -0.060 \\
\hline Voice of accountability & & & $-1.868^{*}$ & & & $0.963^{*}$ & & & $0.927^{* *}$ \\
\hline Political Stability & & & $4.388 * *$ & & & $9.324 * * *$ & & & $0.190 * *$ \\
\hline Government Effectiveness & & & -8.618 & & & $-3.796 *$ & & & 0.232 \\
\hline Regulatory Quality & & & $7.712 * *$ & & & 9.854 & & & 0.739 \\
\hline Rule of Law & & & -1.325 & & & $9.165^{*}$ & & & -0.653 \\
\hline Control of Corruption & & & -69.19 & & & -99.73 & & & 21.150 \\
\hline R2, adj. & 0.2707 & 0.3376 & 0.4244 & 0.3369 & 0.3941 & 0.6281 & 0.6197 & 0.7333 & 0.7378 \\
\hline Number of observations & 143 & 143 & 143 & 78 & 78 & 78 & 65 & 65 & 65 \\
\hline
\end{tabular}

Table shows results for pooled OLS regressions with White's standard errors.

$*, * *$, and $* * *$ show significance at $10 \%, 5 \%$ and $1 \%$.

Source: Own computation 
Table 6 Determinants of money market mutual fund industry size in CEE economies, pooled OLS

\begin{tabular}{|c|c|c|c|c|c|c|c|c|c|}
\hline \multirow[b]{2}{*}{ Intercept } & \multicolumn{3}{|c|}{ All economies } & \multicolumn{3}{|c|}{ High-income economies } & \multicolumn{3}{|c|}{ Middle-income economies } \\
\hline & -286.41 & $-320.68 *$ & $-196.20 * *$ & -136.17 & $-175.07 *$ & $-162.71 * * *$ & $-66.73 *$ & $12.348^{*}$ & $38.397 * *$ \\
\hline log GDP/capita (const. P, USD pc 2005) & $28.658 *$ & $25.246 * *$ & $13.728 * *$ & $143.136 * *$ & $172.112 * *$ & $134.846 * * *$ & 7.106 & $2.367 * *$ & -2.151 \\
\hline$(\mathrm{Ex}+\mathrm{Im}) / \mathrm{GDP}(\%)$ & $0.198 * *$ & $0.526 *$ & $0.531 *$ & 0.200 & 0.930 & $0.549 *$ & 0.016 & -0.284 & $-0.242 *$ \\
\hline Central government debt / GDP (\%) & $0.817 * *$ & $1.245^{* *}$ & $1.346 * *$ & $-1.222 * * *$ & $1.698^{* *}$ & $-2.720 *$ & $0.184 * *$ & $0.061 * *$ & $0.064 *$ \\
\hline FDI net/GDP (\%) & $1.628 * *$ & $0.723 * *$ & $0.653 * *$ & $1.991 * * *$ & 0.619 & $0.412 *$ & $0.229 * * *$ & $-0.125 * *$ & $0.575^{* *}$ \\
\hline log Internet users (per 100 inhabitants) & 0.200 & -0.096 & -0.009 & -0.011 & -0.551 & -0.251 & 0.428 & 0.518 & 0.389 \\
\hline Cap gross/GDP (\%) & & 0.000 & 0.001 & & $0.000 *$ & 0.001 & & 0.000 & 0.000 \\
\hline Turnover ratio (Stocks traded/Cap) & & $-0.003 *$ & -0.001 & & $0.002 *$ & 0.000 & & $-0.001^{*}$ & $-0.001 *$ \\
\hline Liquidity ratio (Stocks traded/GDP) & & $0.009 *$ & -0.005 & & $0.000 *$ & -0.006 & & -0.003 & -0.005 \\
\hline MSCI return & & $0.495 * * *$ & $0.427 * *$ & & $0.701 * * *$ & $0.602 * * *$ & & $-0.081 * *$ & $0.001 * *$ \\
\hline MSCI volatility & & $0.070 *$ & $1.482 * *$ & & $-3.769 *$ & $-1.906 * *$ & & $0.236 *$ & $0.002 * *$ \\
\hline Real interest rate $(\%)$ & & 0.027 & 0.010 & & $0.054 *$ & 0.023* & & $0.020 *$ & $0.007 *$ \\
\hline Bank assets gross/GDP (\%) & & 0.019 & $0.103 * * *$ & & $0.061 *$ & $-0.109 *$ & & $0.015^{*}$ & $-0.006 *$ \\
\hline Insurance assets gross/GDP (\%) & & 0.194 & -1.462 & & 0.014 & -2.750 & & 0.348 & -0.353 \\
\hline Voice of accountability & & & $0.928 *$ & & & $2.421 *$ & & & $0.116 *$ \\
\hline Political Stability & & & $0.891 * * *$ & & & $2.567 * * *$ & & & $0.759 * *$ \\
\hline Government Effectiveness & & & 2.393* & & & $2.695 * *$ & & & $0.312^{*}$ \\
\hline Regulatory Quality & & & $2.505 * *$ & & & $0.151 * *$ & & & $0.322 * *$ \\
\hline Rule of Law & & & 1.202 & & & 7.834 & & & 0.016 \\
\hline Control of Corruption & & & $1.201 *$ & & & 5.798* & & & $0.895^{*}$ \\
\hline R2, adj. & 0.3184 & 0.3563 & 0.4597 & 0.3751 & 0.4879 & 0.6506 & 0.5421 & 0.6572 & 0.6630 \\
\hline Number of observations & 148 & 148 & 148 & 78 & 78 & 78 & 65 & 65 & 65 \\
\hline
\end{tabular}

Table shows results for pooled OLS regressions with White's standard errors

$*, * *$, and $* * *$ show significance at $10 \%, 5 \%$ and $1 \%$.

Source: Own computation 
If we consider attributes of development and growth of particular segments of the mutual fund industry, such as equity, fixed income and money market mutual funds, these attributes are very close to the ones which we observed in case of overall CEE asset management, but with some exceptions. In general, there is a significant positive relationship between decrease of central government debt, development of local financial and capital markets, improvement of quality of governance and development of local equity mutual funds. Growth of national government indebtedness negatively effects the development of local equity mutual funds in all CEE economies, while increase of inhabitants' disposable income stimulates growth of local equity asset management. The effect of the later one is more significant in high-income economies, while the effect of the former is more significant in middle-income economies. This can be explained by higher share of fixed income and money markets mutual funds in middle-income CEE economies, thus higher sensitivity of local asset management to changes in central government debt, and higher share of equity mutual funds in highincome CEE economies: when there is an increase in national government indebtedness in middle-income CEE economies there is reorientation in capital flows - there is a dry up of capital inflows for local equity funds in favor of capital inflows for local fixed income and money market funds; in the case of highincome economies, the local population has better investment opportunities offered by local stockmarkets, thus delegating their savings to local equity asset managers. An increase in local stock market turnover and liquidity as well as local stock market return and volatility has a positive impact on development of equity mutual funds in all CEE economies, however in high-income economies this impact is higher than in their middle-income counterparts. Growth of local banking industry is equally important for development of equity asset management in both income groups. As for quality of governance and regulatory basis, political stability and government effectiveness are the most important determinants of growth of equity mutual funds in all CEE economies.

As for the segment of fixed income mutual funds, in general, there is a significant positive relationship between an increase of country openness to trade and capital inflows, development and stability of local financial and capital markets, improvement of quality of governance and development of local fixed income asset management. In particular, an increase of national economy's openness to trade and FDI is crucially important for growth of local fixed income funds. This is true for both income groups. Additionally to this common regional condition, for development of fixed income funds in high-income economies the increase of the central government debt plays an important role. This can be explained by the fact that fixed income funds are the predominant type of funds in CEE and the main type of their assets are government bonds and eurobonds (Lemeshko and Mukhacheva, 2014). Besides economic development, development of local financial and capital markets is also important for growth of local fixed income assets management: there is a significant positive relationship between increase in local stock market return, turnover and liquidity with simultaneous decrease in 
its volatility on growth of fixed income mutual funds in all CEE economies. However, in high-income CEE economies this impact is higher rather than in their middle-income counterparts. This can be explained by higher degree of interconnection between high-income CEE economies and their financial and capital markets in comparison with middle-income CEE economies. Contrary to this, development of the banking industry is more beneficial for middle-income economies' fixed income mutual funds, which can be again explained by higher role of the banking sector rather than capital markets in development of middle income CEE economies. As for quality of governance and regulatory quality, like in case of equity mutual funds, political stability and regulatory quality are the most significant factors for growth of fixed income asset management, which is equally important in both income groups.

Likewise in previous cases of equity and fixed income mutual funds, the development and growth of the last, but not the least segment of CEE asset management industry, that is, money market mutual funds, is substantially effected by increase of country openness to trade and capital inflows, development and stability of local financial and capital markets, improvement of quality of governance. In general, there is a significant positive relationship between increase in inhabitants' disposable income, country's openness to trade and FDI and growth of money market mutual funds in all CEE economies. Increase in local stock markets return is another factor of CEE money market funds development. Here it is necessary to mention, that although the impact of stock market return is similar in high- and middle CEE economies, nevertheless its volatility has a different impact: money market funds in high-income CEE economies grow faster under condition of low stock market volatility, while middle-income CEE economies require some degree of volatility for growth. This can be explained by higher growth potential of stock markets from middle-income economies and its interconnection with growth potential of local money market asset management. Likewise in case of equity and fixed income mutual funds, development of banking sector is equally important for growth of money market mutual funds in both income groups. As for quality of governance, so in case of money market mutual funds extension it is the most crucial role (in comparison with cases of equity and fixed income mutual funds) - five out of six basic attributes of quality of governance and regulatory basis are required - voice and accountability, political stability, government effectiveness, regulatory quality and control of corruption. This can be explained by the particularly demanding regulatory and legislative environment, which is necessary for effective operation of money market mutual funds and connected with this high risk for wellfunctioning of national economies.

The obtained evidence on equity, fixed income and money market funds is in compliance with previous findings of Klapper et al. (2004), Khorana et al. (2005), Tulbure and Catarama (2009). In general it is possible to conclude, that all categories of mutual funds as well as the whole asset management industry in 
the CEE positively respond on between increase of country openness to trade and capital inflows, development and stability of local financial and capital markets, improvement of quality of governance and regulatory basis. Effect of change in national government indebtedness is controversial: its increase represents a source for further growth in the case of fixed income and money market funds from middle-income economies, while in the case of local equity funds it creates a kind of barrier; as for high-income asset management its decrease is more favorable for all categories of funds rather than its increase.

\section{Conclusions}

The fast changing world of international capital markets and asset management industry during the last decade experienced emergence and rapid development of new players from Central and Eastern Europe. These high- and middle-income CEE economies have all chances to become powerful competitors for their counterparts from developing economies in the world, and provide good investment opportunities for investors from developed economies.

The existing literature predicts that development of mutual fund industry depends on a number of factors among which the predominant role belongs to economic and financial system development and quality of governance and regulatory basis. This paper reevaluates on the sample of high- and middle-income CEE economies the impact of factors identified in previous studies. This study departs from previous ones by using a new database of more than 5000 open-end equity, fixed income and money market mutual funds operating in CEE during the last 13 years. Although the chosen sample does not cover as large number of countries as previous studies, it provides an insight into CEE fund industry, documenting important country and regional characteristics. Following established practice, for evaluation of significance of particular growth factors and development attributes the size of the mutual fund industry, given by its market capitalization to GDP ratio is regressed by means of pooled OLS over a number of independent variables, data on which was collected from a wide range of sources.

The obtained results have two dimensions. First of all, many factors, the high explanatory power of which was stressed by earlier studies, turned out to be insignificant in our research. Among factors, whose impact at $95 \%$ significance has not proved itself, there are national income heterogeneity, literacy and mass media coverage rates, susceptibility to financial contingency and crisis, capital market turnover and degree of bank concentration and intermediation in transfer of funds. This can be explained by the earlier stated fact that relevant studies were structured mainly upon mature economies and, thus, their generalizations and prediction may not work in the environment of developing economies. The second dimension is confirmation of significance of a rather small number of factors, whose role in development of asset management works in both developed and developing economies. In particular, there was found a strong 
positive relationship between mutual fund industry size and national income, openness to trade and national government indebtedness. Further a strong positive effect of growth was found in local stock markets liquidity and return, bank assets to GDP ratio, and indices referring to voice and accountability, government effectiveness, regulatory quality, and a strong negative impact of growth in stock market volatility, real interest rate and political stability on development and growth of local mutual fund industries.

As for particular segments of the mutual fund industry, such as equity, fixed income and money market funds, the earlier mentioned relationships hold within these segments with some exceptions and particularities. In general it is possible to conclude, that all categories of mutual funds in the CEE positively respond to increase of country openness to trade and capital inflows, development and stability of local financial and capital markets, improvement of quality of governance and regulatory basis. As for particularities, so for growth of CEE equity mutual fund industry an important role is played by the decrease of central government debt, while for fixed income mutual fund industry the opposite condition is true (i.e. increase in central government debt). This situation is especially controversial in middle-income CEE economies. The growth of the money market mutual fund industry is substantially effected by the increase of country openness to trade and capital inflows and improvement of quality of governance. The latter is especially important for all CEE economies - five out of six basic attributes of quality of governance and regulatory basis are required.

The obtained results might be extended by further study of CEE funds riskadjusted ability to beat the market and, if any, determinants of it.

\section{Acknowledgements}

Support of Masaryk University within the project MUNI/A/1127/2014 "Analýza, tvorba a testování modelů oceňování finančních, zajištovacích a investičních aktiv a jejich využití k predikci vzniku finančních krizí" is gratefully acknowledged.

\section{References}

Adams, J. C., Mansi, S. A. and Nishikawa, T. (2012). Are mutual fund fees excessive? Journal of Banking \& Finance, 36(8), pp. 2245-2259.

Agnesens, J. (2013). A statistically robust decomposition of mutual fund performance. Journal of Banking \& Finance, 37(10), pp. 3867-3877.

Ammann, M., Kind, A. and Seiz, R. (2010). What drives the performance of convertible-bond funds? Journal of Banking \& Finance, 34(11), pp. 2600-2613.

Aspalter, C., Jinsoo, K. and Sojeung, P. (2009). Analysing the Welfare State in Poland, the Czech Republic, Hungary and Slovenia: An Ideal-Typical Perspective. Social Policy \& Administration, 43(2), pp. 170-185. 
Bakker, M.-R. and Gross, A. (2004). Development of non-bank financial institutions and capital markets in European union accession countries. World Bank Working Paper no. 28. Available at: https://ideas.repec.org/b/wbk/wb pubs/15030.html.

Banegas, A., Gillen, B., Timmermann, A. and Wermers, R. (2013). The cross section of conditional mutual fund performance in European stock markets. Journal of Financial Economics, 108(3), pp. 699-726.

Bauer, R., Koedijk, K. and Otten, R. (2005). International evidence on ethical mutual fund performance and investment style. Journal of Banking \& Finance, 29(7), pp. 1751-1767.

Beck, T., Demirgüç-Kunt and Levine, R. (2010). Financial Institutions and Markets across Countries and over Time. World Bank Economic Review, 24(1), pp. 77-92.

Bell, G. G. and Deng, S. (2013). Beyond clusters: How regional geographic signature affects firm value and risk. Canadian Journal of Administrative Sciences, $30(2), 71-85$.

Bengtsson, E. and Delbecque, B. (2011). Revisiting the European asset management industry. Financial Markets, Institutions \& Instruments, 20(4), pp. 163-190.

Benos, E. and Jochec, M. (2011). Short term persistence in mutual fund market timing and stock selection abilities. Annals of Finance, 7(2), pp. 221-246.

Benson, K. L. and Humphrey, J. E. (2008). Socially responsible investment funds: Investor reaction to current and past returns. Journal of Banking \& Finance, 32(9), pp. 1850-1859.

Białkowski, J. and Otten, R. (2011). Emerging market mutual fund performance: Evidence for Poland. The North American Journal of Economics and Finance, 22(2), pp. 118-130.

Bollen, N. P. B. and Busse, J. A. (2004). Short-Term Persistence in Mutual Fund Performance. The Review of Financial Studies, 18(2), pp. 569-597.

Christoffersen, S. E. K. and Sarkissian, S. (2009). City size and fund performance. Journal of Financial Economics, 92(2), pp. 252-275.

Čihák, M., Demirgüç-Kunt, S., Feyen, E. and Levine, R. (2012). Benchmarking Financial Development Around the World. World Bank Policy Research Working Paper 6175.

Cojocaru, L., Hoffman, S. D. and Miller, J. B. (2011). Financial development and economic growth in transition economies: Empirical evidence from the CEE and CIS countries. University of Delaware, Working Paper 2011-22. 
Cuthbertson, K., and Nitzsche, D. (2013). Performance, stock selection and market timing of the German equity mutual fund industry. Journal of Empirical Finance, 21, pp. 86-101.

Cuthbertson, K., Nitzsche, D. and O'Sullivan, N. (2008). UK mutual fund performance: Skill or luck? Journal of Empirical Finance, 15(4), pp. 613-634.

Dariusz Filip, D. F. (2011). Performance Persistence of Equity Funds in Hungary. Contemporary Economics, 5(1), pp. 18-34.

Demirgüç-Kunt, A., Feyen, E. and Levine, R (2011). The Evolving Importance of Banks and Securities Markets. World Bank Policy Research Working Paper 5805.

Dubofsky, D. A. (2010). Mutual fund portfolio trading and investor flow. Journal of Banking \& Finance, 34(4), pp. 802-812.

Erdős, P. and Ormos, M. (2009). Return calculation methodology: Evidence from the Hungarian mutual fund industry. Acta Oeconomica, 59(4), pp. 391-409.

Fernando, D., Klapper, L., Sulla, V. and Vittas, D. (2003). The global growth of mutual funds. World Bank Development Research Group Working Paper No. 3055. Available at: http://papers.ssrn.com/sol3/papers.cfm?abstract_id=636417.

Geranio, M. and Zanotti, G. (2005). Can mutual funds characteristics explain fees? Journal of Multinational Financial Management, 15(4-5), pp. 354-376.

Gottesman, A. and Morey, M. (2012). Mutual fund corporate culture and performance. Review of Financial Economics, 21(2), pp. 69-81.

Gottesman, A. A. and Morey, M. R. (2006). Manager education and mutual fund performance. Journal of Empirical Finance, 13(2), pp. 145-182.

Harper, J. T., Madura, J. and Schnusenberg, O. (2006). Performance comparison between exchange-traded funds and closed-end country funds. Journal of International Financial Markets, Institutions and Money, 16(2), pp. 104-122.

Havrylchyk, O. (2009). Will Western European Banks pull out of Central and Eastern Europe? La Lettre du CEPII, (288).

Hughen, J. C. and Mathew, P. G. (2009). The efficiency of international information flow: Evidence from the ETF and CEF prices. International Review of Financial Analysis, 18(1-2), pp. 40-49.

Huij, J. and Derwall, J. (2007). "Hot Hands" in bond funds. Journal of Banking \& Finance, 32(4), pp. 559-572.

Jackowicz, K. and Kowalewski, O. (2012). Crisis, internal governance mechanisms and pension fund performance: Evidence from Poland. Emerging Markets Review, 13(4), pp. 493-515.

Jackowicz, K., Kowalewski, O. and Kozlowski, L. (2011). The Short and Long Term Performance Persistence in the Central European Banking 
Industry. Contemporary Economics, 5(4). Available at: https://ideas.repec.org/a/ wyz/journl/id224.html.

Jank, S. and Wedow, M. (2008). Sturm und Drang in money market funds: when money market funds cease to be narrow. Deutsche Bundesbank Research Centre Discussion Paper Series No 20/2008. Available at: https://ideas.repec.org/p/zbw /bubdp2/200820.html.

Karagiannidis, I. (2010). Management team structure and mutual fund performance. Journal of International Financial Markets, Institutions and Money 20(2), pp. 197-211.

Karagiannidis, I. (2012). The effect of management team characteristics on risktaking and style extremity of mutual fund portfolios. Review of Financial Economics, 21(3), pp. 153-158.

Kaufmann, D., Kraay, A. and Mastruzzi, M. (2009). Governance Matters VIII: Aggregate and Individual Governance Indicators, 1996-2008. World Bank Policy Research Working Paper 4978.

Khorana, A., Servaes, H. and Tufano, P. (2005). Explaining the size of the mutual fund industry around the world. Journal of Financial Economics, 78(1), pp. 145185.

Klapper, L., Sulla, V. and Vittas, D. (2004). The development of mutual funds around the world. Emerging Markets Review, 5(1), pp. 1-38.

La Porta, R., Lopez-de-Silanes, F., Shleifer, A. and Vishny, R. W. (1998). Law and finance. Journal of Political Economy, 106(6), pp. 1113-1155.

Laeven, L. and Valencia F. (2012). Systemic Banking Crises Database. IMF Economic Review, 61, pp. 225-270. DOI: 10.1057/imfer.2013.12.

Lemeshko O. and Mukhacheva G. (2014). Emerging markets mutual funds performance evaluation: Evidence from the Central and Eastern Europe. In SGEM Conference on Political Sciences, Law, Finance, Economics and Tourism Conference Proceedings - Volume II Finance, pp. 241-248. DOI: 10.5593/ sgemsocial2014B22.

Narulita, W. A. and Parwada, J. T. (2012). Evolution of a mutual fund market: Empirical analysis of simultaneous growth and decline by fund category in Indonesia. Journal of International Financial Markets, Institutions and Money, 22(5), pp. 1217-1236.

Poshakwale, S. and Thapa, C. (2011). Investor protection and foreign equity portfolio investments. Global Finance Journal, 22(2), pp. 116-129.

Prather, L., Bertin, W. J. and Henker, T. (2004). Mutual fund characteristics, managerial attributes, and fund performance. Review of Financial Economics, 13(4), pp. 305-326. 
Rakowski, D. and Wang, X. (2009). The dynamics of short-term mutual fund flows and returns: A time-series and cross-sectional investigation. Journal of Banking \& Finance, 33(11), pp. 2102-2109.

Ramos, S. B. (2009). The Size and Structure of the World Mutual Fund Industry. European Financial Management, 15(1), pp. 145-180.

Thapa, C. and Poshakwale, S. (2010). International equity portfolio allocations and transaction costs. Journal of Banking and Finance, 34(11), pp. 2627-2638.

Thapa, C. and Poshakwale, S. (2012). Country-specific equity market characteristics and foreign equity portfolio allocation. Journal of International Money and Finance, 31(2), pp. 189-211.

Tulbure, N. and Catarama, D. (2009). Institutional and Socio-Cultural Factors Explaining the Development of Mutual Funds. A Cross-Country Analysis. MPRA Paper. Available at: http://mpra.ub.uni-muenchen.de/20341/.

Varga, G. and Wengert, M. (2010). The growth and size of the Brazilian mutual fund industry. Munich Personal RePEC Archive. Available at: http://mpra.ub.unimuenchen.de/21581/.

Vidal-García, J. (2013). The persistence of European mutual fund performance. Research in International Business and Finance, 28, pp. 45-67.

Vinkler, P. (2012). The case of scientometricians with the "absolute relative" impact indicator. Journal of Informetrics, 6(2), pp. 254-264.

Walter, A. and Moritz Weber, F. (2006). Herding in the German mutual fund industry. European Financial Management, 12(3), pp. 375-406. 